\title{
Manajemen Komunikasi Krisis Desa Wisata Pulesari dalam Menghadapi Pandemi Covid-19
}

\author{
Yani Tri Wijayanti \\ UIN Sunan Kalijaga, Yogyakarta, Indonesia \\ Contact: yani.wijayanti@uin-suka.ac.id
}

\begin{abstract}
The Covid-19 Pandemic that has hit Indonesia for last two years has had an impact on all sectors of life, including the tourism sector. The impact is felt to the tourist villages, one of which is Pulesari Tourism Village. A very significant decline in tourist visits since March 2020, even having to close for a few months, this has an impact on the economic condition of the surrounding community, because this tourist village is managed by the community themselves. The pandemic is one of the causes of the crisis. This study aims to find out how tourism village crisis communication management is in the face of the covid-19 pandemic. The method used is a case study. The results obtained based on the stages of the crisis passed, as well as analysis of crisis management, the right strategy is adaptive strategy. For crisis communication management, there are three main principles in crisis communication, namely speed of conveying messages, consistency and openness. Crisis communication management that can be done by tourism village managers is by developing communication strategies, delivering messages regularly, optimizing communication channels by utilizing social media and providing input to policy makers.
\end{abstract}

Keywords: Crisis, Crisis Communication Management, Covid-19 Pandemic, Pulesari Tourism Village

\begin{abstract}
ABSTRAK
Pandemi covid-19 yang telah melanda Indonesia hampir dua tahun terakhir membawa dampak dalam segala sektor kehidupan, tidak terkecuali sektor pariwisata. Dampak ini dirasakan hingga sampai ke desa wisata, salah satunya adalah Desa Wisata Pulesari. Menurunnya kunjungan wisatawan yang sangat signifikan sejak Bulan Maret 2020, bahkan sempat harus tutup beberapa bulan, hal ini berdampak pada kondisi ekonomi masyarakat sekitar, karena desa wisata ini dikelola oleh masyarakat sendiri. Pandemi merupakan salah satu penyebab krisis terjadi. Penelitian ini bertujuan untuk mengetahui bagaimana manajemen komunikasi krisis desa wisata dalam menghadapi pandemi covid19. Metode yang digunakan studi kasus. Hasil penelitian didapatkan berdasarkan tahapan krisis yang dilalui, serta analisis manajemen krisis maka strategi yang tepat adalah adaptive strategy. Untuk manajeman komunikasi krisis yaitu terdapat tiga prinsip utama dalam komunikasi krisis yakni kecepatan menyampaikan pesan, konsisten dan terbuka. Manajemen komunikasi krisis yang bisa dilakukan oleh pengelola desa wisata dengan mengembangkan strategi komunikasi, menyampaikan pesan secara berkala, mengoptimalkan saluran komunikasi dengan memanfaatkan media sosial yang dan serta memberikan masukan kepada pemangku kebijakan.
\end{abstract}

Kata Kunci : Krisis, Manajemen Komunikasi Krisis, Pandemi Covid-19, Desa Wisata Pulesari

\section{Pendahuluan}

Pandemi Covid-19 telah melanda Indonesia sejak awal Maret 2020, hampir dua tahun kita hidup dalam situasi pandemi. Pandemi ini membawa banyak perubahan dalam segala sektor kehidupan, banyak masyarakat kita yang terdampak oleh pandemi. Salah satu yang merasakan dampak besar dari adanya pandemi adalah sektor pariwisata, banyak pelaku usaha bidang pariwisata yang harus merasakan kesedihan karena mengalami kerugian secara materi dan tentu berdampak pada kehidupan ekonomi mereka. Industri pariwisata disebut sangat rentan terhadap berbagai faktor, di antaranya adalah bencana alam, wabah penyakit (pandemi), terorisme, pemberontakan, dan sebagainya. Pengelola pariwisata perlu 
mempersiapkan dengan dalam menghadapi krisis ini, serta perlu disiapkan strategi pemulihan yang baik (Yeh, 2020).

Wakil Ketua Perhimpunan Hotel dan Restoran Indonesia (PHRI) Maulana Yusran mengatakan, saat ini industri pariwisata, hotel dan restoran menderita kerugian mencapai lebih dari Rp 100 triliun atau US\$ 7,1 miliar hingga awal November. Kerugian tersebut terjadi karena adanya pandemi Covid-19 yang akhirnya berdampak pada semua industri pariwisata (Fitri,2020). Bahkan menurut Kemenparekraf (2021), sepanjang tahun 2020 jumlah wisatawan mancanegara yang masuk ke Indonesia hanya sekitar 4,052 juta orang. Angka tersebut sangat memprihatinkan, karena dari total tersebut hanya sekitar $25 \%$ dari jumlah wisatawan yang masuk ke Indonesia pada 2019. Hal ini pun berdampak pada pendapatan negara di sektor pariwisata. Adanya pembatasan sosial berskala besar dan ditutupnya akses keluar-masuk Indonesia, menyebabkan penurunan pendapatan negara di sektor pariwisata sebesar Rp20,7 miliar.

Seiring dengan data secara nasional di atas, DI Yogyakarta menjadi salah satu provinsi di Indonesia yang mengalami kerugian di masa pandemi covid-19 ini. Dimana kita tahu Yogyakarta mempunya banyak destinasi wisata mulai dari wisata budaya, wisata sejarah, wisata alam, wisata kuliner, dan sebagainya. Kerugian yang dialami tidak sedikit di bidang pariwisata selama pandemi ini, selama enam belas bulan terakhir, sektor pariwisata mati suri. Aneka pembatasan mobilitas menambah berat beban pelaku industri ini. Yogyakarta, yang menjadi salah satu tujuan wisata populer di Indonesia, kehilangan Rp10 triliun sepanjang pandemi. Angka Rp10 triliun tersebut adalah perhitungan omset bisnis anggota Gabungan Industri Pariwisata Indonesia (GIPI) Daerah Istimewa Yogyakarta saja. Jika sektor terkait diikutkan, menurut Ketua GIPI DIY, Bobby Ardyanto Setya Aji, kerugiannya bisa melonjak hingga Rp25 triliun (Sucahyo, 2021).

Dampak pandemi di Yogyakarta tentunya juga dialami di Kabupaten yang berada di provinsi ini, salah satunya adalah Kabupaten Sleman. Kabupaten yang dikenal dengan banyak potensi wisata. Kepala Dinas Pariwisata Suparmono menyampaikan, bahwa sampai dengan November 2021, kunjungan wisatawan di Kabupaten Sleman adalah sebanyak 704.748 kunjungan, bila dibandingkan dengan jumlah kunjungan wisatawan pada periode yang sama pada tahun 2020, maka terdapat penurunan kunjungan sebesar 81,48 persen (Wawan,2021). Kondisi krisis dialami oleh hampir semua destinasi wisata di wilayah Kabupaten Sleman. Tak terkecuali Desa Wisata Pulesari. Desa yang terletak di bawah kaki Gunung Merapi yang mempunyai potensi alam dan budaya yang luar biasa. Ketika wabah melanda, terjadi penurunan jumlah pengunjung yang sangat signifikan. Irwanto (2021) selaku Ketua Pengelola Desa Wisata Pulesari, menyampaikan bahwa kunjungan wisatawan di Desa Wisata Pulesari sebelum pandemi, bulan Januari 2020 mencapai 5.984 orang, tetapi di bulan Januari 2021 jumlah pengunjung hanya di angka 137 orang. Terdapat penurunan yang sangat signifikan, hal ini tentunya sangat berpengaruh pada perekonomian masyarakat Desa Wisata Pulesari yang selama ini banyak bergerak di sektor pariwisata.

Terkait penyebutan desa wisata, sering kali terdapat salah pemahaman. Desa wisata dan objek wisata di desa merupakan dua hal yang berbeda namun sering kali susah untuk 
dibedakan. Saat ini banyak desa yang menyatakan bahwa desanya merupakan desa wisata, ternyata setelah dikaji secara mendalam hanyalah sebuah desa yang memiliki objek wisata. Keberadaan objek wisata, baik berupa wisata alam maupun wisata event bukan serta merta dapat dikatakan bahwa desa tersebut merupakan desa wisata. Menurut Nuryanti (dalam Antara, 2015), desa wisata merupakan suatu bentuk integrasi antara atraksi, akomodasi dan fasilitas pendukung yang disajikan dalam suatu struktur kehidupan masyarakat yang menyatu dengan tata cara dan tradisi yang berlaku. Joshi (dalam Antara 2015), juga menyampaikan bahwa desa wisata (rural tourism) merupakan pariwisata yang terdiri dari keseluruhan pengalaman pedesaan, atraksi alam, tradisi, unsur-unsur unik yang secara keseluruhan dapat menarik minat wisatawan. Subagyo menambahkan, kehidupan desa sebagai tujuan wisata adalah desa sebagai objek sekaligus juga sebagai subjek dari kepariwisataan yaitu sebagai pihak penyelenggara sendiri dari berbagai aktivitas kewisataan dan hasilnya akan dinikmati oleh masyarakat secara langsung, maka peran aktif masyarakat sangat menentukan kelangsungan kegiatan desa wisata ini.

Desa yang memiliki potensi wisata yang dapat dimanfaatkan sebagai atraksi wisata, memiliki aksesibilitas, dan sudah memiiki aktivitas wisata, seperti Desa Wisata Pulesari yang berada dekat dengan aktivitas wisata penyangga Kawasan Taman Nasional Gunung Merapi serta memiliki sumber daya alam yang melimpah, seperti Desa Pulesari. Desa yang terletak di Pulesari, Kalurahan Wonokerto Kapanewon Turi, Kabupaten Sleman. Desa Wisata Pulesari berupa Kawasan pedesaan yang mempunyai potensi yang dapat menarik pengunjung, potensi inilah yang dijadikan sebagai tujuan wisata, mampu menyajikan wisata alam dan budaya tradisi secara komprehensif. Akses jalan untuk menuju Desa Wisata Pulesari cukup mudah bisa ditempuh dari pusat Kota Yogyakarta, dengan sekitar jarak tempuh 21 kilometer, dan ditempuh kurang lebih 40 menit. Karena akses jalan yang sudah bagus, pengunjung bisa menggunakan kendaraan jenis motor, mobil maupun dengan menggunakan bis.

Desa Wisata Pulesari diluncurkan sejak tanggal 9 November 2012 oleh Dinas Kebudayaan dan Pariwisata Kabupaten Sleman. Tujuannya adalah memajukan dan mempromosikan potensi Desa Pulesari baik sumber daya alam maupun budayanya. Bahkan Desa ini pernah mendapatkan Juara I Festival Desa Wisata Kategori Mandiri Kabupaten Sleman di Tahun 2018. Desa ini merupakan desa penghasil buah salak, yang kemudian oleh masyarakat diolah menjadi berbagai makanan olahan seperti wajik salak, nastar salak, wingko salak, dodol salak, bahkan ada sambel salak. Fasilitas yang disediakan oleh Desa Wisata Pulesari menurut Irwanto (2021), seperti penginapan (homestay), aula, pendapa, sekretariat, tempat bermain (playground), rumah makan, tempat parkir yang luas, rumah ibadah, serta akses jalan yang mudah. Sehingga fasilitas yang telah disediakan oleh pengelola ini mampu mendukung sarana prasarana dari aktivitas kepariwisataan yang ada di Desa Wisata Pulesari.

Potensi wisata lainnya di Desa Wisata Pulesari diantaranya adalah outbond dengan didukung beragam wahana seperti jembatan goyang, titian bambu, vertical web, hujan buatan, tangga air, titian tali dan jaring laba-laba; ada beragam wisata budaya seperti tarian, kerajinan, kuliner serta wisata keluarga yang nyaman, terdapat pula wisata sejarah, setidaknya terdapat delapan goa yang terdapat di desa tersebut yaitu Goa Dampar, Goa Canguk, Goa Grenjeng, Goa 
Wayang, Goa Gedhe, Goa Ular, Goa Bedhog dan Goa Leri; dan masih banyak lagi potensi wisata yang mampu membangun perekonomian masyarakat Desa Pulesari. Desa Wisata Pulesari mempunyai berbagai adat dan tradisi besar, terdapat dua tradisi besar yaitu Acara Sadranan dan Upacara Pagar Bumi. Melalui dua tradisi tersebut mempunyai tujuan menjaga kearifan lokal dan kerukunan serta karakter masyarakat yaitu gotong royong, dua tradisi ini yang selanjutnya diangkat menjadi potensi budaya yang dapat dipromosikan di wisatawan baik lokal, nasional maupun internasional.

Desa wisata terdapat tipe berdasarkan pola, proses dan pengelolaaannya, desa atau kampung wisata di Indonesoa terbagi dalam dua tipe yaitu (1) Tipe terstruktur/daerah kantong (enclave), tipe ini ditandai dengan lahan wisata yang dilengkapi dengan infrastruktur yang spesifik untuk kawasan tersebut, memiliki kelebihan dalam citra yang ditumbuhkannya, sehingga mampu menempus pasar internasional. Tipe ini pada umumnya berlokasi terpisah dari masyarakat atau penduduk lokal, sehingga dampak negatif yang ditimbulkan dapat diminimalisir, dan pencemaran sosial budaya yang ditimbulkan bisa terdeteksi sejak dini. Selain itu lahannya biasanya tidak terlalu besar dan masih dalam tingkat kemampuan perencanaan yang integratif dan terkoordinasi. (2) Tipe Terbuka (spontaneous), tipe ini ditandai dengan karakter-karakter yaitu tumbuh menyatunya kawasan dengan struktur kehidupan, baik ruang maupun pola dengan masyarakat lokal. Distribusi pendapatan yang didapat dari para wisatawan dapat langsung dinikmati oleh penduduk lokal. Akan tetapi dampak negatifnya adalah cepat menjalar menjadi satu dalam penduduk lokal, sehingga sulit dikendalikan (Antara, 2015).

Namun di masa pandemi ini semua wisata yang ada di Desa Wisata Pulesari harus ditutup, bahkan tidak ada pengunjung yang datang sehingga tidak ada pendapatan sama sekali. Dengan adanya kebijakan social distancing dan physical distancing akibat pandemi covid-19 menimbulkan gangguan pada sektor pariwisata. Dengan adanya kebijakan ini, desa wisata sepi pengunjung, tidak ada pendapatan dan berdampak pada pelaku pariwisata di desa tersebut. Krisis yang dialami oleh sektor pariwisata selama pandemi covid-19 terkait dengan penurunan jumlah pengunjung, penurunan ini tentunya tidak lepas dari adanya kebijakan pemerintah dan kecemasan saat mengunjungi tempat pariwisata. Pengunjung juga cemas ada ketakutan terpapar covid-19. Oleh karenanya pelaku pariwisata harus bisa membangun komunikasi yang baik dengan para calon wisatawan.

Pada saat pandemi, kunjungan wisatawan sepi. Bahkan menurut Irwanto (2021), berdasarkan data kunjungan Desa Wisata Pulesari Tahun 2020, di Bulan April sampai dengan Bulan September tidak ada kunjungan sama sekali, mengingat adanya kebijakan dari pemerintah dan disebabkan situasi pandemi yang sedang pada puncaknya. Baru Bulan Oktober 2020, pengelola desa wisata berani kembali membuka dengan kunjungan yang rata-rata masih sedikit. Berdasarkan pengamatan langsung penulis, wisatawan yang datang kebanyakan adalah wisatawan lokal saja.

Kondisi yang dihadapi oleh Desa Wisata Pulesari selama pandemi covid-19 dapat dikatakan sebagai krisis. Krisis bisa disebabkan salah satunya adalah wabah penyakit yang melanda masyarakat. Dalam situasi krisis seperti ini diperlukannya manajemen krisis yang baik 
dan dapat dikomunikasi dengan baik pula kepada stakeholders. Tujuan dari pengelolaan krisis menurut Seitel (2004), adalah untuk mengakhiri krisis secepatnya, meminimalkan kerusakan yang diakibatkan dan juga memperbaiki kredibilitas. Strategi sebagai langkah manajemen komunikasi krisis sangat diperlukan oleh pelaku pariwisata di desa wisata untuk dapat mengembalikan kondisi seperti semula, dapat meningkatkan jumlah pengunjung. Pelaku pariwisata di Desa Wisata Pulesari perlu membangun komunikasi efektif dengan calon wisatawan untuk dapat menumbuhkan kepercayaan calon wisatawan untuk berkunjung ke Desa Wisata Pulesari.

Krisis menurut Devlin (dalam Kriyantono, 2012), didefinisikan sebagai "an unstable time for an organization, with a distinct possibility for an undesirable outcome", yang dapat diartikan sebagai situasi yang tidak diinginkan. Borodzics mengatakan bahwa krisis lebih dari sekedar situasi darurat (emergency), sebagai situasi yang membahayakan yang dapat diatasi dengan menggunakan prosedur-prosedur atau mekanisme-mekanisme normal, sehingga penyebab dan akibat yang ditimbulkannya dapat diprediksi.

Steven Fink (dalam Kasali, 2005) mengidentikkan krisis dengan penyakit yang menyerang manusia. Fink, membagi tahapan yang dilalui suatu krisis dengan menggunakan terminologi kedokteran, yaitu dengan tahapan-tahapan sebagai berikut : (1) Tahap Prodromal, tahap ini sebagai kondisi dimana suatu krisis besar biasanya dimulai dengan adanya krisis yang kecil-kecil sebagai pertanda atau gejala awal. Tahap ini sering juga disebut sebagai warning stage, karena memberi sirene tanda bahaya mengenai simtom-simtom yang harus segera diatasi; (2) Tahap Akut, tahap ini sering dikatakan "telah terjadi krisis". Tahap ini sebagai the point of no return. Ditandai dengan kerusakan sudah mulai bermunculan, reaksi mulai berdatangan, isu menyebar luas, dan ada kemungkinan intensitas serangan dari berbagai pihak ada di dalam tahap ini; (3) Tahap Kronik, tahap ini dapat disebut sebagai tahap recovery atau self analysis, kalau di dalam perusahaan bisa ditandai dengan penggantian manajemen, penggantian pemilik, mungkin juga perusahaan mengalami kebangkrutan dan (4) Tahap Resolusi, tahap ini menjadi tahap penyembuhan dan tahap terakhir dari tahapan krisis yang ada. Steven Fink mendefinisikan sebagai masa-masa dimana perusahaan yang bersangkutan akan bangkit kembali seperti sedia kala, setelah melalui proses perbaikan serta pemulihan citra untuk mengembalikan nama perusahaan di mata khalayaknya.

Untuk menangani krisis diperlukan pengelolaan krisis yang baik dan tepat. Pengelolaan krisis ini perlu dikomunikasikan dengan stakeholders baik internal maupun eksternal. Menurut Kasali (2005), dalam mengelola krisis terdapat langkah-langkah sebagai berikut (1) Identifikasi Krisis, untuk mengidenfikasi suatu krisis perlu dilakukan penelitian. Langkah penelitian ini merupakan penetapan untuk mengetahui (identifikasi) suatu masalah krisis, karena ini adalah hal yang penting, untuk melihat kejelasan sebagai faktor yang menyebabkan timbulnya krisis; (2) Analisis Krisis, sebelum dikomunikasikan perlu dilakukan analisis krisis, yaitu membaca permasalahan. Analisis yang dilakukan memiliki cakupan yang luas, mulai dari analisis parsial sampai analisis integral yang kait mengkait. Beberapa pertanyaan yang diajukan untuk menetapkan penangulangan krisis, yakni : (a) Apa penyebab terjadinya krisis itu - What; (b) Kenapa krisis itu bisa terjadi - Why; (c) Di mana dan kapan krisis tersebut itu terjadi - Where 
and When; (d) Sejauh mana krisis tersebut berkembang - How far; (e) Bagaimana krisis itu terjadi - How; dan (f) Siapa-siapa yang mampu mengatasi krisis tersebut, perlu dibentuk suatu tim penanggulangan krisis - Who. Langkah berikutnya (3) Isolasi Krisis, krisis merupakan penyakit, untuk mencegah krisis menyebar luas ia harus diisolasi, dikarantinakan sebelum tindakan serius dilakukan; (4) Pilihan Strategi. Sebelum mengambil langkah-langkah komunikasi untuk mengendalikan krisis, perlu dilakukan penetapan strategi generik yang akan diambil. Ada 3 strategi generik untuk menangani krisis, yaitu : defensive strategy, adaptive strategy dan dynamic strategy dan (5) Program Pengendalian. Merupakan langkah penerapan yang dilakukan menuju strategi generik yang dirumuskan. Umumnya strategi generik dapat dirumuskan jauh-jauh hari sebelum krisis timbul, yakni sebagai guidance agak dapat mengambil langkah yang pasti.

Lukaszewski (dalam Iriantara, 2004), menunjukkan unsur-unsur prioritas dalam manajemen krisis yaitu : (1) menyelesaikan masalah yang menimbulkan krisis; (2) membantu korban dan orang yang langsung terpengaruh krisis; (3) berkomunikasi dengan karyawan dan mengupayakan dukungan karyawan; (4) memberikan informasi kepada pihak-pihak yang secara tak langsung terpengaruh krisis; dan (5) secara tegas mengelola media dan pihak-pihak luar. Dari pendapat Lukaszewski menunjukkan pentingnya pengelolaan krisis dan mengkomunikasikan kepada stakeholders yang ada.

Aktivitas fungsi manajemen komunikasi, sebuah krisis bisa mencakup kekurangan dan ketidakpastian komunikasi. Public Relations menyarankan manajemen untuk menerapkan strategi komunikasi yang memungkinkan organisasi beradaptasi dengan situasi di lingkungannya. Salah satu upaya menyediakan informasi secara regular adalah menyediakan informasi yang setiap saat dapat diakses. Strategi komunikasi dalam krisis biasa disebut komunikasi krisis (crisis communication), yang merupakan bagian dari strategi manajemen krisis. Seperti definisi dari Coombs (2010), komunikasi krisis adalah "collection, processing and dissemination of information required to address a crisis situation". Karenanya dapat disimpulkan bahwa "communication is the essence of crisis management" (Kriyantono,2012).

Penelitian sebelumnya oleh Putri dan Andhita (2021) dengan judul Strategi Komunikasi Krisis Pengelola Desa Wisata Dam Jati dalam Menghadapi Pandemi Covid-19, membahas bagaimana strategi komunikasi krisis pengelola desa wisata dengan menggunakan Teori Komunikasi Krisis Situasional atau Situational Crisis Communication Theory (SCCT) dari Coombs, dengan hasil penelitian bahwa manajemen krisis yang dilakukan pengelola objek wisata Dam Jati dalam menghadapi pandemi covid-19 diterapkan melalui beberapa strategi respon krisis yang sesuai dengan Situational Crisis Communication Theory, pengelola menghadap krisis dengan cara mengurangi kerusakan yang diakibatkan krisis melalui strategi justification dan compensation. Kahardja (2022) meneliti terkait Strategi Komunikasi Mempertahankan Reputasi Organsasi dalam Manajemen Krisis dengan Menggunakan Teori Komunikasi Krisis Situasional. Menyampaikan hasil bahwa penerapan SCCT dalam penanganan krisis yaitu dengan menggunakan media sosial dan memperkuat strategi komunikasi dengan penggunaan bahasa, dialek, dan pendekatan adat istiadat. Dari dua penelitian sebelumnya ini 
banyak membahas pada strategi, sedangkan dalam penelitian ini membahas manajemen komunikasi krisis.

Berdasarkan paparan di atas, melalui penelitian ini, penulis ingin merumuskan permasalahan yaitu bagaimana manajemen komunikasi krisis desa wisata dalam menghadapi pandemi covid-19? Dengan tujuan bisa menggambarkan manajemen komunikasi di saat krisis di Desa Wisata Pulesari dalam menghadapi pandemi covid-19, dilihat dari tahap krisis, langkahlangkah dari manajemen krisis serta manajemen komunikasi krisis.

\section{Metode}

Metode yang digunakan adalah metode kualitatif dengan strategi studi kasus. Creswell (2016) menyatakan bahwa studi kasus ialah suatu serangkaian kegiatan ilmiah yang dilakukan secara intensif, terinci dan mendalam tentang suatu program, peristiwa, dan aktivitas, baik pada tingkat perorangan, sekelompok orang, lembaga, atau organisasi untuk memperoleh pengetahuan mendalam tentang peristiwa tersebut.

Desa Wisata Pulesari, Wonokerto, Kabupaten Sleman, DI Yogyakarta dalam penelitian ini sebagai subjek, sedangkan objek penelitian adalah manajemen komunikasi krisis pada desa wisata dalam menghadapi pandemi Covid-19. Pemilihan narasumber menggunakan teknik purposive sampling. Data primer dalam penelitian ini didapat dengan melakukan wawancara mendalam dengan Pengelola Desa Wisata. Observasi dilakukan dengan melakukan pengamatan langsung ke lokasi di Desa Wisata Pulesari. Data sekunder yang digunakan berupa mencari informasi melalui buku, jurnal, dokumen resmi terkait, website serta media sosial. Analisis data dengan menggunakan model Miles dan Huberman, yaitu reduksi data, penyajian data dan penarikan kesimpulan (Sugiyono, 2016). Keabsahan data menggunakan triangulasi sumber untuk mengungkap dan menganalisis masalah-masalah yang dijadikan sebagai subjek dalam penelitian ini.

\section{Hasil dan Pembahasan}

Pandemi Covid-19 sudah berlangsung sejak awal Maret Tahun 2020, sudah hampir dua tahun masyarakat Indonesia mengalami banyak perubahan dalam segala sektor kehidupan. Tentunya yang paling terasa adalah perubahan dalam sektor ekonomi, terjadinya penurunan pendapatan atau bahkan sampai harus kehilangan pekerjaan atau mata pencaharian dikarenakan situasi pandemi. Selama masa pandemi covid-19 Desa Wisata Pulesari mengalami banyak kerugian, karena sepinya pengunjung. Padahal masyarakat di desa ini menggantungkan hidupnya pada aktivitas pariwisata di desa ini. Kondisi ini dapat dikatakan sebagai kondisi krisis, karena salah satu penyebab krisis diantaranya adalah adanya wabah penyakit.

Krisis yang dialami oleh masyarakat di Desa Wisata Pulesari, dapat dikaji dengan melihatan tahap-tahap krisis yang ada, seperti yang dikemukakan oleh Steven Fink ada empat tahap yaitu : Tahap Prodromal, Tahap Kronis, Tahap Akut dan Tahap Resolusi. Dalam kasus ini, krisis yang terjadi bukan di sebuah organisasi, lembaga atau perusahaan yang nanti biasanya ditangani oleh Public Relations atau Humasnya, tetapi dalam hal ini krisis yang terjadi pada sebuah desa wisata yang pengelolanya adalah masyarakatnya sendiri. Dari empat tahap tersebut bila dilihat dalam kasus di Desa Wisata Pulesari adalah sebagai berikut : 


\section{Tahap Prodromal}

Tahap ini adalah munculnya tanda-tanda atau gejala awal. Coombs, 2010; Devlin, 2007; Smudde, 2001 dalam Kriyantono (2012) menyebutnya sebagai tahapan prakrisis, dimana situasi serius mulai muncul dan organisasi mulai menyadarinya. Pada tahap ini, situasi krisis di Desa Wisata Pulesari ditandai dengan adanya Pandemi Covid-19 yang mulai melanda di wilayah Indonesia pada umumnya, dan Yogyakarta pada khususnya yaitu di Bulan Maret 2020. Desa Wisata Pulesari merasakan mulainya awal krisis adalah di Bulan Maret dimana tingkat kunjungan wisatawan mulai menurun drastis. Menurut Ketua Pengelola Desa Wisata Pulesari, bahwa pengunjung di Bulan Januari 2020, ada 5984 wisatawan; Bulan Februari 5761 wisatawan, dan di Bulan Maret sudah mengalami penurunan yang sangat signifikan, yaitu hanya ada 1619 wisatawan yang berkunjung ke Desa Wisata Pulesari. Bahkan Bulan April hingga September 2020 tidak ada kunjungan sama sekali (Irwanto, 2021). Baru Bulan Oktober mulai berani membuka kunjungan wisata kembali, dan jumlah wisatawan yang berkunjung pun masih sangat sedikit hanya di rentang 100-250 wisatawan yang berkunjung setiap bulannya.

Ketua Forum Komunikasi (Forkom) Desa Wisata Sleman Doto Yogantoro mengatakan secara umum terjadi penurunan jumlah kunjungan wisatawan ke desa-desa wisata. Kondisi tersebut tidak terlepas dari wabah virus Corona atau Covid-19 yang melanda dunia. "Banyak yang rencana kunjungan wisatawan yang cancel. Kondisi ini hampir semua kena, baik lokal maupun nasional," (Atmasari, 2020). Irwanto (2021) juga menambahkan bahwa jumlah wisatawan luar negeri yang berkunjung ke Pulesari selama ini memang tidak banyak. Ditambah lagi setelah tragedi Susur Sungai Sempor siswa SMP N 1 Turi yang menyebabkan adanya korban meninggal 10 siswi, dan puluhan siswa yang terluka yang terjadi pada tanggal 21 Februari 2020.

Berdasarkan fakta di lapangan yang dihadapi oleh masyarakat Desa Wisata Pulesari menunjukkan bahwa tanda adanya krisis mulai melanda di desa wisata tersebut adalah sepinya pengunjung serta adanya tragedi susur sungai. Gejala krisis ini memang sulit untuk diantisipasi di awal, karena pandemi ini adalah wabah yang melanda secara global, sehingga kedatangannya tidak bisa dicegah dengan mudah. Idealnya sebuah krisis ketika baru terjadi gejala langsung bisa ditangani supaya tidak meningkat ke tahap berikutnya. Tapi kasus pandemi tidak bisa dengan mudah ditangani, berbeda dengan krisis yang disebabkan kerusakan produk, kesalahan manajemen, produk yang kadaluarsa atau produk yang dikatakan mengandung zat berbahaya yang bisa ditangani perusahaan melalui prosedur yang sudah ada. Gejala krisis yang tidak bisa ditangani secara langsung dan cepat diantaranya adalah bencana alam dan pandemi, dapat dipastikan akan meningkat ke tahap krisis berikutnya yaitu ke tahap akut dan seterusnya.

\section{Tahap Akut}

Tahap ini adalah mulai terjadinya krisis, terjadi kerusakan, kehancuran, kerugian. Pada tahap ini Desa Pulesari mengalami banyak kerugian. Irwanto (2021), menyampaikan, kerugian yang dialami oleh masyarakat adalah sekitar 200 jutaan, dan kondisi ini berdampak pada merosotnya pendapatan masyarakat karena tidak adanya pemasukan. Masyarakat 
Desa Pulesari selain sebagai petani Salak, karena Buah Salak menjadi komoditas pertanian, sebagian besar masyarakat juga mengandalkan hidupnya di sektor pariwisata. Ada yang bekerja sebagai guide yang mendampingi wisatawan saat berkunjung, mengolah salak menjadi produk yang dipasarkan ke wisatawan, menyediakan jasa katering, menyediakan jasa penginapan atau homestay, sebagai pengisi acara (tari), dan sebagainya.

Dalam kondisi pandemi buah salak melimpah tetapi tidak bisa diolah menjadi makanan yang lebih punya nilai jual tinggi. Karena produk yang dihasilkan dari olahan Buah Salak ini oleh masyarakat hanya dijual kepada para wisatawan yang berkunjung saja. Bahkan harga salak pun anjlog, Salak Pondoh dari lereng Merapi yang terkenal ini hanya dipatok harga sekitar Rp 1000 hingga 3000 setiap kilonya dari petani, ditambah terhentinya ekspor Buah Salak ke luar negeri karena pandemi terdapat berbagai kendala. Akibatnya tidak sedikit petani yang membiarkan Buah Salak di kebun mereka membusuk daripada dipanen.

\section{Tahap Kronis}

Pada tahap kronis disebut sebagai tahap recovery atau tahap pemulihan. Pengelola Desa Wisata Pulesari serta para pemangku kebijakan mulai melakukan langkah-langkah untuk bisa bangkit lagi dari keterpurukan karena pandemi. Irwanto (2021) menyampaikan bahwa dalam rangka persiapan membuka kembali layanan paket wisata di Desa Wisata Pulesari, menyiapkan sarana prasarana yang mendukung protokol kesehatan, di antaranya wastafel. Dan kesiapan-kesiapan teknis seperti dilakukannya simulasi dengan Gugus Tugas Covid-19.

Selain itu juga melakukan pembenahan fasilitas-fasilitas yang ada, karena selama pandemi fasilitas itu tidak pernah terpakai, perlu dilakukan checking wahana dan fasilitas wisata yang ada. Dalam kesiapan membuka kunjungan wisata lagi, sudah disiapkan fasilitas di antaranya adalah tempat cuci tangan yang terlah terpasang di 30 titik, thermogun sejumlah 10 buah, disinfektan serta hand sanitizer, dna tentunya juga dipasang poster serta baliho yang memperingatkan kepada para wisatawan untuk tetap mematuhi protokol kesehatan seperti wajib menggunakan masker, mencuci tangan dengan menggunakan sabun, dan menjaga jarak atau yang biasa kita singkat dengan 3M. Irwanto (2021) juga menambahkan bahwa untuk penanganan bila terjadi penularan covid-19, pihak pengelola desa wisata sudah berkoordinasi dengan Satgas Covid-19 Kalurahan Wonokerto, Kapanewon Turi untuk menyiagakan satu unit ambulans, yang bisa digunakan oleh warga. Persiapan lain adalah masyarakat di desa tersebut sudah divaksin covid-19 sebagai upaya untuk meningkatkan imunitas dan mencegah penyebaran virus covid-19.

Dalam membuka desa wisata, pengelola tidak ingin buru-buru. Sebab destinasi wisata seperti desa wisata merupakan wisata yang berbasis masyarakat. Untuk membuka kembali kegiatan pariwisata di masa pandemi covid-19 harus siap dengan protokol kesehatan pariwisata dan juga kondisi masyarakat. Menurut Irwanto (2021) "Kami tidak mau buruburu, kalau persiapan belum sesuai regulasi “. Pengelola tidak ingin memaksakan diri untuk buru-buru membuka, ditakutkan nanti malah membawa masalah bagi masyarakatnya sendiri, yaitu justru meningkatkan jumlah penyebaran virus covid-19 di desa wisata ini. 


\section{Tahap Resolusi}

Tahap ini disebut sebagai tahap penyembuhan atau pulih kembali. Walaupun secara global pandemi covid-19 masih ada tetapi tentunya pengelola desa wisata tidak tinggal diam, untuk mulai bangkit melakukan perbaikan-perbaikan, mengembalikan lagi kepercayaan masyarakat yang akan berkunjung ke Desa Wisata Pulesari. Langkah yang dilakukan adalah menyiapkan Standar Operasional Prosedur (SOP) baik bagi petugas maupun bagi wisatawan.

Pengelola bahkan telah menyiapkan dua spot tambahan yang baru yaitu foodcourt dan camping area. Di foodcourt akan disediakan sentra kuliner, panggung akustik dan juga sebagai galeri produk Usaha Mikro Kecil Menengah (UMKM) warga sekitar. Sedangkan camping area akan disediakan juga panggung pertunjukan, toilet dan juga homestay. Pembangunan fasilitas ini mendapatkan dukungan dari Kemetnerian Desa melalui Program Pembangunan Usaha Pariwisata.

Dengan SOP yang ada baik untuk petugas maupun wisatawan diharapkan mampu memberikan rasa tenang dan nyaman kepada wisatawan, bahwa desa wisata ini memang sudah siap menerima kunjungan tanpa abai protokol kesehatan. Membuat desa wisata ini menjadi semakin menarik dengan menyiakan spot baru, apalagi disini nanti produk-produk UMKM juga bisa di-display supaya pengunjung juga bisa melihat langsung produk-produk unggulan dari desa wisata ini. Dan tentunya bisa menambah semangat lagi para pelaku UMKM Desa Wisata Pulesari.

Secara ringkat dari tahap-tahap krisis yang ada di Desa Wisata Pulesari dapat dilihat dalam gambar berikut ini :

Gambar 1 Tahapan Krisis Desa Wisata Pulesari

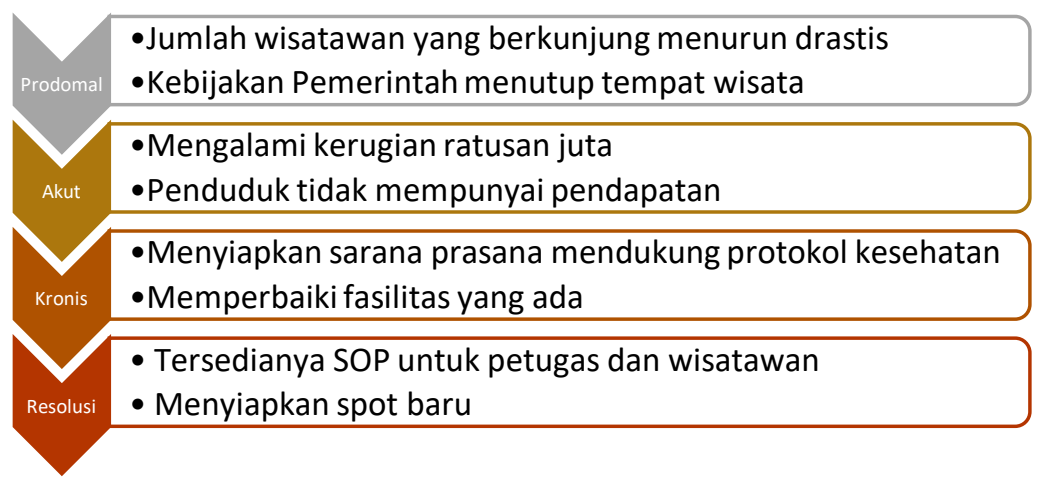

Sumber : Olahan Penulis

Untuk tahapan selajutnya dalam pengelolaan krisis adalah dengan melakukan langkahlangkah dalam mengelola krisis, seperti pendapat Kasali (2005), dengan langkah-langkah sebagai berikut ini :

\section{Identifikasi Krisis}

Identifikasi krisis dilakukan oleh pengelola dengan melakukan pendataan masalah krisis yang dihadapi oleh Desa Wisata Pulesari. Bahwa krisis yang dihadapi sudah jelas disebabkan karena adanya pandemi covid-19 yang mengakibatkan penurunan pendapatan masyarakat 
desa wisata tersebut. Bahkan mereka sempat tutup beberapa bulan karena adanya larangan dari pemerintah untuk membuka tempat wisata, praktis hal ini menjadi masalah yang besar bagi masyarakat terutama sektor ekonomi.

\section{Analisis Krisis :}

Analisis krisis dilakukan dengan menjawab pertanyaan untuk penanggulangan krisis, pertanyaan tersebut meliputi :

- Apa penyebab krisis : Penurunan jumlah wisatawan yang datang ke Desa Wisata Pulesari

- Kenapa krisis itu bisa terjadi : Karena adanya pandemi covid-19, sehingga pemerintah melarang pembukaan tempat wisata dan larangan berpergian, dan kecemasan masyarakat

- Di mana dan kapan krisis tersebut terjadi : Di Desa Wisata Pulesari, sejak Maret 2020

- Sejauh mana krisis tersebut berkembang : Sampai saat ini jumlah kunjungan wisatawan masih rendah, masyarakat mengalami penurunan pendapatan.

- Bagaimana krisis itu terjadi : Krisis terjadi karena adanya wabah penyakit yang diakibatkan virus covid-19, dan ini menjadi pandemi global.

- Siapa-siapa yang mampu mengatasi krisis : Krisis ini terjadi secara global, seluruh dunia juga mengalami. Untuk mengatasinya saat ini belum bisa, yang bisa dilakukan adalah melakukan pencegahan supaya penyebarannya tidak semakin luas.

\section{Isolasi Krisis}

Isolasi krisis dilakukan supaya krisis tidak menyebar, supaya tidak meluas. Krisis yang terjadi karena wabah penyakit atau pandemi agak sulit tentunya melakukan isolasi atau karantina supaya tidak menyebar. Mengingat virus covid-19 ini menyebar begitu cepat. Hal yang bisa dilakukan adalah melakukan pencegahan untuk mengurangi penyebarannya yaitu dengan melakukan protokol kesehatan secara ketat. Mematuhi semua peraturan yang telah ditetapkan.

\section{Pilihan Strategi}

Langkah ini adalah memilih strategi generik dalam menangani krisis. Dalam kasus ini, langkah strategi yang tepat adalah Adaptive Strategy. Menurut Kasali (2005), langkah ini mencakup hal-hal : mengubah kebijakan, modifikasi operasional, kompromi dan meluruskan citra. Terkait hal ini yang bisa dilakukan oleh pengelola desa wisata adalah (1) mengubah kebijakan tentunya kebijakan ini merupakan turunan dari kebijakan pemerintah pusat; (2) modifikasi operasional yaitu dengan membuat SOP yang harus dipatuhi oleh wisatawan dan petugas, supaya aktivitas pariwisata di desa wisata berjalan dengan baik dan taat protokol kesehatan; (3) kompromi, dengan melakukan kompromi dengan situasi, bagaimana pun saat ini yang bisa dilakukan adalah menjalani aktivitas dengan berdampingan dengan pandemi. Bagaimana pun kehidupan harus terus berjalan, masyarakat juga perlu melanjutkan kehidupan, dengan melaksanakan aktivitas tetapi dengan menyesuaikan situasi yang ada; dan (4) meluruskan citra, pengelola dapat melakukan langkah strategis dengan memanfaatkan media sosial yang ada untuk bisa kembali menginformasikan situasi di desa wisata, bagaimana 
pelayanan kepariwisataan selama pandemi, fasilitas pendukung apa saja yang disediakan untuk mendukung protokol kesehatan, wahana apa saja yang sudah dibuka, dan sebagainya.

\section{Program Pengendalian}

Program pengendalian sebagai langkah untuk mewujudkan startegi generik. Melalui strategi adaptif, harapannya adalah para pengelola dan masyarakat dapat mengimplementasikan startegi ini dengan baik. Dan ketika strategi ini berhasil, maka bisa dijadikan pedoman ketika krisis lain terjadi.

Dari langkah-langkah dalam mengelola krisis, berdasarkan studi kasus krisis yang terjadi di desa wisata, penulis secara ringkas menggambarkan sebagai berikut :

\section{Gambar 2 Manajemen Krisis Desa Wisata Pulesari}

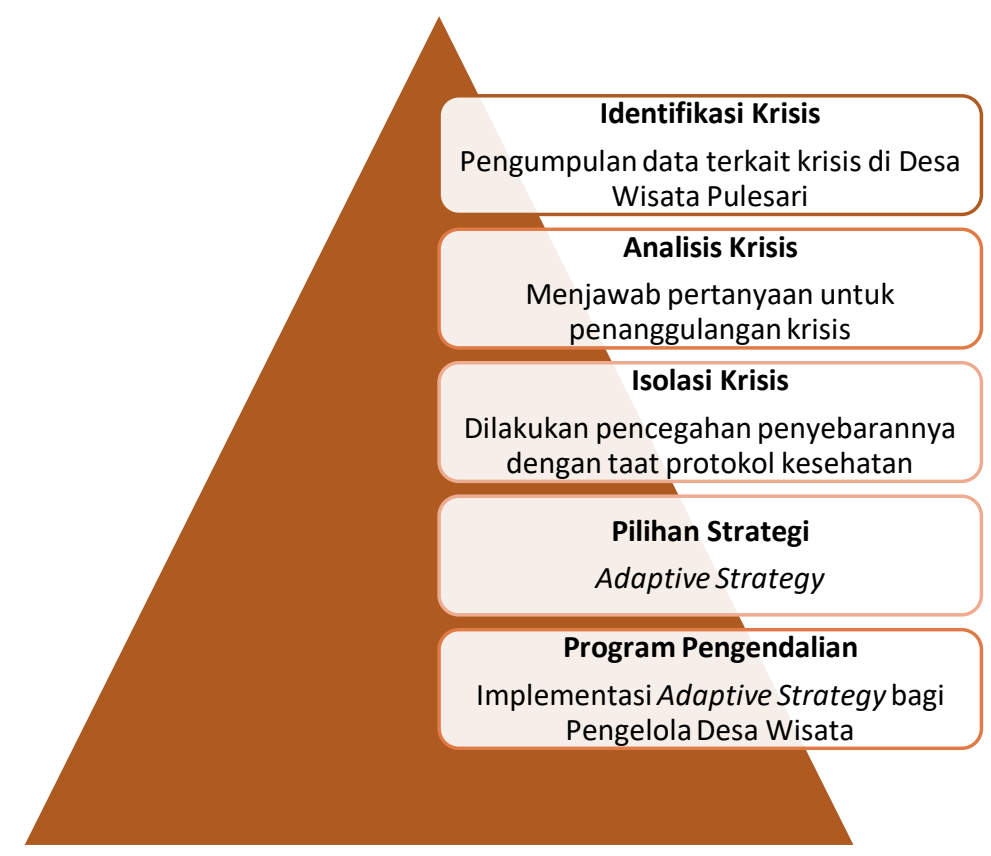

Sumber : Olahan Penulis

Hal yang tidak boleh terlewatkan dalam penanganan krisis yaitu komunikasi. Komunikasi yang dilakukan dengan baik oleh pengelola desa wisata menjadi hal yang mutlak dibutuhkan oleh stakeholders baik internal maupun eksternal. Dalam komunikasi dengan stakeholders elemen yang penting adalah informasi. Bila informasi yang disampaikan salah, maka akan menambah kebingungan terutama saat pandemi seperti ini. Dalam rangka mengelola krisis untuk pemulihan yaitu dengan penerapan kenormalan baru dalam sektor pariwisata, maka informasi yang disampaikan dipastikan akurat, kredibel dan relevan. Komunikasi krisis di masa kenormalan baru berperan penting menentukan arah pengembangan sektor pariwisata di masa datang (Paramita, 2020).

Menurut Mulyana (dalam Sahputra, 2020), strategi komunikasi merupakan panduan perencanaan komunikasi (communication planning) dengan manajemen komunikasi (communication management) untuk mencapai tujuan yang telah ditetapkan. Strategi komunikasi ini harus mampu menunjukkan bagaimana operasionalnya secara praktis harus 
dilakukan. Coombs (dalam Prastya, 2011) menyampaikan ada tiga prinsip utama dalam komunikasi krisis yakni menyampaikan pesan dengan cepat atau segera menyampaikan pesan, konsisten dan terbuka. Kecepatan, kecepatan dalam menyampaikan pesan. Pengelola desa wisata harus cepat memberikan informasi kepada para stakeholdersnya. Kecepatan memberikan informasi dapat berdampak pada keterpenuhan informasi yang valid dan dapat dipercaya; Konsisten, konsistensi dalam setiap informasi yang disampaikan atau pesan yang disampaikan kepada stakeholders, yaitu dengan menunjuk juru bicara atau spokesperson. Yang menjadi juru bicara untuk media selama ini adalah Ketua Pengelola Desa Wisata yaitu Irwanto (2021). Penunjukan juru bicara tentu tidak serta merta menyelesaikan persoalan krisis, dibutuhkan upaya lain berupa pengaturan pesan-pesan yang komprehensif (Suherman, 2020); Keterbukaan, prinsip ini mewajibkan pengelola desa wisata untuk berbagi informasi secara terbuka kepada stakeholders terhadap apa yang terjadi dan aktivitas apa saja yang dilakukannya selama pandemi covid-19.

Pentingnya komunikasi krisis sebagai bagian dalam manajemen krisis seperti yang disampaikan Coombs (dalam Prastya, 2011), bahwa komunikasi krisis adalah "darah kehidupan" dari seluruh kegiatan manajemen krisis dan memainkan peran vital di setiap tahap dari manajemen krisis. Manajemen komunikasi krisis yang bisa dilakukan oleh pengelola desa wisata diantaranya adalah melakukan langkah-langkah sebagai berikut : (1) mengembangkan strategi komunikasi dengan memanfaatkan media sosial; (2) menyampaikan informasi secara berkala kepada para calon wisatawan mengenai penerapan protokol kesehatan di desa wisata; (3) mengoptimalkan saluran komunikasi dan konten digital desa wisata. Media sosial dan website yang telah dimiliki dimaksimalkan; (4) memberikan masukan kepada para pemangku kebijakan untuk ikut mendukung usaha pemulihan krisis di Desa Wisata Pulesari.

Komunikasi supaya bisa berjalan efektif perlu memperhatikan beberapa indikator yaitu : penerima, isi pesan, ketepatan waktu, media komunikasi, format dan juga sumber pesannya. Dengan memperhatikan keenam indikator tersebut diharapkan apa yang dikomunikasikan dapat diterima dengan baik oleh receiver. Yang dilakukan oleh pengelola desa wisata ini sudah mulai memperhatikan keenam indikator tersebut dalam pembuatan konten/pesan di media sosial. Penyampaian pesan melalui media sosial sebagai langkah komunikasi krisis di era new media, dengan memaksimalkan media sosial untuk mempromosikan destinasi pariwisata yang yang ada di Desa Wisata Pulesari, sebagai langkah untuk memulihkan dari situasi krisis. Desa Wisata Pulesari telah memiliki media sosial Facebook, Instagram, Twitter, serta Website berbasis Blog. Berdasarkan pengamatan penulis, di Tahun 2021 pengelola desa wisata sudah mulai aktif kembali penggunaanya walaupun belum maksimal dan belum informatif. Media sosial memberikan informasi mengenai destinasi wisata, fasilitas/sarana prasarana yang ada, hal ini menjadi langkah yang bagus melakukan komunikasi pemasaran melalui media sosial dalam rangka pemulihan krisis.

\section{Simpulan}

Manajemen komunikasi krisis yang dilakukan oleh Desa Wisata Pulesari dalam menghadapi pandemi covid-19 dimulai dengan mengkaji tahap-tahap krisis yaitu tahap prodromal, tahap akut, tahap kronis dan tahap resolusi. Sedangkan untuk menganalisis 
manajemen krisis dilihat dari langkah-langkah menangani krisis yang ada, yang disebabkan karena adanya pandemi covid-19. Dengan adaptive strategy, yaitu mengubah kebijakan, modifikasi operasional, kompromi dan meluruskan citra, maka keempat hal tersebut juga perlu dikomunikasikan ke stakeholders yang ada baik internal maupun eksternal, dengan memanfaatkan media sosial yang ada, sekaligus juga sebagai langkah komunikasi pemasaran. Terdapat tiga prinsip utama dalam komunikasi krisis yakni kecepatan menyampaikan pesan, konsisten dan terbuka. Manajemen komunikasi krisis adalah mengelola komunikasi sebagai langkah untuk menangani krisis. Manajemen komunikasi krisis yang bisa dilakukan oleh pengelola desa wisata diantaranya adalah melakukan langkah-langkah sebagai berikut : mengembangkan strategi komunikasi, menyampaikan pesan secara berkala, mengoptimalkan saluran komunikasi dengan memanfaatkan media sosial yang dan serta memberikan masukan kepada pemangku kebijakan. Sehingga dengan manajemen komunikasi yang baik bisa dijadikan solusi untuk menangani krisis pada Desa Wisata Pulesari.

Penulis memberikan saran kepada para pemangku kebijakan yang terkait dapat memperhatikan desa wisata yang terdampak pandemi dengan memberikan program-program yang dapat membangkitkan kembali desa wisata dan memulihkannya kunjungan wisata supaya perekonomian masyarakat di desa tersebut juga bisa kembali normal. Untuk pengelola desa wisata bisa lebih memaksimalkan pemanfaatan media sosial yang sudah dimiliki untuk menginformasikan ke khalayak luas tentang potensi yang dimiliki.

\section{Daftar Pustaka}

Antara, M dan Arida, I.N.S. (2015). Panduan Pengelolaan Desa Wisata Berbasis Lokal. Denpasar : Pustaka Larasan. Atmasari, N. (13 Maret 2020). Selain Dipicu Virus Corona, Desa Wisata Makin Sepik arena Pembatasan Outbond Pascakasus Susur Sungai Sempor. https://jogjapolitan.harianjogja.com/read/2020/03/13/512/1034154/selain-dipicu-virus-corona-desawisata-makin-sepi-karena-pembatasan-outbond-pascakasus-susur-sungai-sempor

Creswell, J. W. (2016). Research Design (Pendekatan Metode Kualitatif, Kuantitatif, dan Campuran). Terjemahan Bahasa Indonesia. Yogyakarta: Pustaka Pelajar.

Fitri, A.N. (16 November 2020). PHRI : Kerugian Industri Pariwisata karena Pandemi Sudah Lebih dari Rp 100 Triliun. https://industri.kontan.co.id/news/phri-kerugian-industri-pariwisata-karena-pandemi-sudah-lebih-darirp-100-triliun

Iriantara, Y. (2004). Manajemen Strategis Public Relations. Jakarta : Ghalia Indonesia.

Irwanto, D (2021, 22 Oktober) Wawancara Pribadi

Kahardja, I.W. (2022). Strategi Komunikasi Mempertahankan Reputasi Organsasi dalam Manajemen Krisis dengan Menggunakan Teori Komunikasi Krisis Situasional. Syntax Literate : Jurnal IImiah Indonesia p-ISSN: 25410849, e-ISSN : 2548-1398, Vol. 7, Special Issue No. 1, Januari 2022. http://dx.doi.org/10.36418/syntaxliterate.v7i1.5738

Kasali, R. (2005). Manajemen Public Relations. Jakarta : Pustaka Utama Grafiti.

Kementerian Pariwisata dan Ekonomi Kreatif. (18 Agustus 2021). Tren Pariwisata Indonesia di Tengah Pandemi. https://kemenparekraf.go.id/ragam-pariwisata/Tren-Pariwisata-Indonesia-di-Tengah-Pandemi

Kriyantomo, R. (2012). Public Relations \& Crisis Management. Pendekatan Critical Public Relations Etnografi Kritis \& Kualitatif. Jakarta : Kencana Prenada Media Group.

Paramita, I.B.G. (2020). Mengelola Komunikasi Efektif Public Relation Sektor Pariwisata di Bali pada Masa Pandemi Covid-19. Rumah Jurnal STAHN Mpu Kuturan Singaraja. Vol. 2, No. 2, 2020 https://stahnmpukuturan.ac.id/jurnal/index.php/communicare/issue/view/153 
Putri, R.N.A. dan Andhita, P.R. (2021). Strategi Komunikasi Krisis Pengelolaan Desa Wisata Dam Jati dalam Menghadapi Pandemi Covid-19. Ekspresi dan Persepsi : Jurnal IImu Komunikasi, Vol. 4, No. 2, Juli 2021. eISSN: 2656-050X. http://dx.doi.org/10.33822/jep.v4i2.2607

Prastya, N.M. (2011). Komunikasi Krisis di Era New Media dan Social Media. Jurnal Komunikasi, ISSN 1907-898X. Volume 6, Nomor 1, Oktober 2011.

Sahputra, D. (2020). Manajemen Komunikasi Suatu Pendekatan Komunikasi. Jurnal Simbolika : Research and Learning in Communication Study. 6 (2) Oktober 2020. ISSN 2442-9198 (Print). ISSN 2442-9996 (Online). https://doi.org/10.31289/simbollika.v6i2.4069

Sigit, A. (24 Agustus 2021). Menikmati Pesona Desa Wisata Pulesari. https://www.krjogja.com/wisata/jalanjalan/menikmati-pesona-desa-wisata-pulesari/

Sucahyo, N. (3 Agustus 2021). Industri Pariwisata Yogyakarta Rugi Rp 10 Triliun Selama Pandemi. https://www.voaindonesia.com/a/industri-pariwisata-yogyakarta-rugi-rp10-triliun-selamapandemi/5988791.html

Wawan, J.H. (20 Desember 2021). Efek Pandemi, Kunjungan Wisatawan ke Selman Turun 81\%. https://travel.detik.com/travel-news/d-5862630/efek-pandemi-kunjungan-wisatawan-ke-sleman-turun$\underline{81}$

Sugiyono. (2016). Metode Penelitian Kualitatif, Kuantitatif, dan R\&D. Metode Penelitian dan Pengembangan Pendekatan Kualitatif, Kuantitatif, dan R\&D. Bandung: Alfabeta

Suherman, A. (2020) Menyoal Komunikasi Krisis Pemerintah dalam Penanganan Pandemi Covid-19. Dalam Krisis Komunikasi dalam Pandemi Covid-19. Editor : Fajar Junaedi. Yogyakarta : Buku Litera.

Yeh, S-S. (2020). Tourism Recovery Strategy Against Covid-19 Pandemic. Tourism Recreation Research. https://doi.org/10.1080/02508281.2020.1805933 